\title{
Effects of Temperature in Juvenile Seabass (Dicentrarchus labrax L.) Biomarker Responses and Behaviour: Implications for Environmental Monitoring
}

\author{
Joana R. Almeida • Carlos Gravato • Lúcia Guilhermino
}

Received: 3 July 2013 /Revised: 17 January 2014 / Accepted: 16 February 2014 / Published online: 6 March 2014

(C) Coastal and Estuarine Research Federation 2014

\begin{abstract}
The effects of temperature on European seabass (Dicentrarchus labrax L.) juveniles were investigated using a 30-day bioassay carried out at 18 and $25{ }^{\circ} \mathrm{C}$ in laboratory conditions. A multiparameter approach was applied including fish swimming velocity and several biochemical parameters involved in important physiological functions. Fish exposed for four weeks to $25^{\circ} \mathrm{C}$ showed a decreased swimming capacity, concomitant with increased oxidative stress (increased catalase and glutathione peroxidase activities) and damage (increased lipid peroxidation levels), increased activity of an enzyme involved in energy production through the aerobic pathway (isocitrate dehydrogenase) and increased activities of brain and muscle cholinesterases (neurotransmission) compared to fish kept at $18{ }^{\circ} \mathrm{C}$. Globally, these findings indicate that basic functions, essential for juvenile seabass surviving and well performing in the wild, such as predation, predator avoidance, neurofunction and ability to face chemical stress may be compromised with increasing water temperature. This may be of particular concern if D. labrax recruitment phase in northwest European estuaries and coastal areas happens gradually in more
\end{abstract}

Communicated by David J. Booth

J. R. Almeida $(\bowtie) \cdot$ L. Guilhermino

CIIMAR/CIMAR - Interdisciplinary Centre of Marine and

Environmental Research, University of Porto, Rua dos Bragas 289, 4050-123 Porto, Portugal

e-mail: joana.reis.almeida@gmail.com

J. R. Almeida

e-mail: jalmeida@ciimar.up.pt

J. R. Almeida • L. Guilhermino

ICBAS - Institute of Biomedical Sciences Abel Salazar de Ciências Biomédicas de Abel Salazar, University of Porto, Rua de Jorge

Viterbo Ferreira no. 228, 4050-313 Porto, Portugal

C. Gravato

CESAM - Department of Biology, University of Aveiro, Campus de Santiago, 3810-193 Aveiro, Portugal warm environments as a consequence of global warming. Considering that the selected endpoints are generally applied in monitoring studies with different species, these findings also highlight the need of more research, including interdisciplinary and multiparameter approaches, on the impacts of temperature on marine species, and stress the importance of considering scenarios of temperature increase in environmental monitoring and in marine ecological risk assessment.

Keywords Temperature $\cdot$ Marine fish $\cdot$ Dicentrarchus labrax Swimming performance $\cdot$ Biomarkers .

Environmental monitoring

\section{Introduction}

As a primary consequence of global warming, the annual mean of water temperature is increasing in diverse estuaries of temperate regions. Even small increases in temperature that are now common in European estuaries and coastal areas (IPCC 2007; Durrieu de Madron et al. 2011) may interfere with spawning, fertilization and early development of several species, including marine species that use estuaries as nursery grounds, and also exclusively estuarine species. Since the success of these initial life-cycle phases is crucial for populations' fitness, the effects of temperature increase on these phases may lead to adverse consequences at population and community levels (Portner 2001). In addition to these immediate consequences, temperature increase may also increase the susceptibility of organisms to stress by the action of simultaneous alterations, including abiotic and biotic changes in their habitat (e.g. salinity variation and food availability), and also the interference of other chemical stressors present in the marine environment (Schiedek et al. 2007; Noyes et al. 2009). Regarding this, alterations at community level and important changes in ecosystem functioning are expected to 
occur, potentially compromising the services that these ecosystems provide. Thus, more knowledge on the effects of temperature on marine species is needed and even more on ecological and economical important species.

Fish are particularly vulnerable to environmental temperature variations due to the lack of body insulation (poikilotherms) aggravated by the blood-water countercurrent respiratory system in the gills that specially contribute to the approximation in fish body/water temperature (Schmidt-Nielsen 1997; Beitinger et al. 2000). As a result, temperature has been identified as one of the most vital abiotic factors for fish, since it can potentially affect all the metabolic, physiological and also ecological aspects and behavioural tendencies of fish life cycle (Moyle and Cech 2003). In fact, if able to do it, fish species can behaviourally choose a preferred range of water temperatures (thermoregulation behaviour), at which physiological processes, growth, reproduction and survival are optimal (Beitinger and Fitzpatrick 1979; Golovanov 2006), determining their thermal ecological niches (Fry 1971; Magnuson et al. 1979). Though, if habitat restriction occurs by thermoregulation behaviour as a consequence of temperature increase, intra- and interspecific competition will increase, leading to ecosystem unbalances.

It is generally described that acute changes in temperature act on physiological processes predictably, with cold temperatures slowing, and warmer temperatures accelerating them (Prosser and Nelson 1981; Montgomery and Macdonald 1990; Schmidt-Nielsen 1997). Thus, within each tolerable temperature range, fish can compensate temperature changes by appropriate alterations in metabolic rates and oxygen consumption (Schmidt-Nielsen 1997). These alterations may induce an initial stress phase (thermal stress) with formation of reactive oxygen species (ROS), which can provoke protein, lipid or DNA damage, and potentially require additional energy (Zhang et al. 2003; Lushchak and Bagnyukova 2006a). All these physiological alterations induced by stress exposure can be measured using biomarkers, which have been considered as useful tools in detecting early adverse effects, and are recommended for ecological quality assessment and environmental risk assessment studies (Thain et al. 2008; Sanchez and Porcher 2009; Fossi et al. 2012). Antioxidant enzymes, levels of oxidative damage, neurotransmission enzymes and energetic metabolism parameters are among the most commonly used biomarkers of fish health status (van der Oost et al. 2003). Antioxidant enzymes [including catalase (CAT), superoxide dismutase (SOD), glutathione peroxidase (GPx) and glutathione reductase (GR)] and levels of lipid peroxidation (LPO) are good indicators of ROS overproduction and induced oxidative damage in cells (Livingstone 2001; LimonPacheco and Gonsebatt 2009). As any stress condition carries additional energetic requirements, biomarkers on anaerobic and aerobic pathways of energy production [e.g. lactate dehydrogenase (LDH) and isocitrate dehydrogenase (IDH) activities, respectively] may provide important indications in terms of global energetic demands towards a stress condition (Nunes et al. 2004; Lima et al. 2007). In addition, the determination of a neurotransmission parameter, as the activity of the enzymes cholinesterases (ChEs), may be useful to demonstrate stress interferences with neural and nervous functions that may compromise other important physiological functions and also behaviour (Tierney 2011). Also, the mechanism of cholinergic neurotransmission is known to be induced by oxidative stress (Melo et al. 2003) and to cause swimming disturbances in goldfish (Carassius auratus) exposed to heat stress (Szabo et al. 2008).

In this context, to reach a comprehensive assessment of the effects of temperature on juvenile fish health status, it seems suitable to consider parameters at different levels of biological organization, including individual (behaviour) and subindividual (physiological) responses using an ecologically relevant multiparameter approach. Therefore, considering the present context of global warming and the need of more knowledge on the effects of temperature increase on the health status of important marine and estuarine species, the objective of the present study was to assess the effects of temperature increase on juvenile European seabass (Dicentrarchus labrax Linnaeus 1758) using an integrated multiparameter approach. This approach consists of several endpoints including fish swimming velocity, a crucial behavioural parameter for fish performance in the wild, and several biomarkers involved in important physiological functions related with fish health status maintenance, namely CAT, SOD, GPx, GR, LPO, brain AChE, muscle ChE, LDH and IDH.

European seabass was selected for the present study as a marine species that spends the early and more susceptible lifecycle phases in European estuaries and coastal areas, where the impacts of temperature increase in a daily and seasonal basis as well as arising from global warming events are likely to be very important. It is also an economical important species being used for human consumption, and that may be adversely affected by temperature increase (Cabral and Costa 2001; Vinagre et al. 2009), particularly considering the areas that are in the southern range of their distribution and in the upper limit of their thermal tolerance. Given its pertinence, this species has been selected in recent studies focusing on this subject, including on thermal tolerance definition (Madeira et al. 2012), and on the effects of climate change and heat waves on mortality, growth, condition (Vinagre et al. 2012c), oxidative stress parameters (Vinagre et al. 2012a) and heat shock protein expression (Vinagre et al. 2012b). However, at the best of our knowledge, the physiological parameters selected for the present study were not previously tested in D. labrax exposed to different temperatures, except two of the antioxidant parameters, LPO levels and CAT activity (Vinagre et al. 2012a). Also, previous studies applied narrow approaches in terms of ecological relevance and highlight the 
need of further base studies including multidisciplinary and integrative approaches as steps forward to the investigation of the effects of global warming in marine species and ecosystems and also to increase the reliability of environmental monitoring tools. The present study aims to increase the knowledge from these perspectives by including parameters at different levels of biological organization for a more comprehensive and ecologically relevant assessment of the effects of temperature on juvenile fish health status and also employing tools that are recommended for environmental monitoring purposes based on species health status in the field of water policy (European Commission 2000, 2008).

\section{Material and Methods}

All experiments were conducted in accordance with ethical guidelines of the European Union Council (Directive 2010/63/EU) and the Portuguese Ministry of Agriculture, Sea, Environment, and Spatial Planning (Decreto-Lei no. 113/2013, 7 August) for the protection of animals used for experimental and other scientific purposes.

\section{Fish Provenience and Transport}

Seabass juveniles from the same batch ( 5 months old; $6.5-\mathrm{cm}$ average length and 5.6-g weight) were purchased from a saltwater fish aquiculture (Vila Nova de Mil Fontes, Portugal) where they were maintained from birth at $17{ }^{\circ} \mathrm{C}$, natural photoperiod and saltwater. Fish from the same brood stock were used to minimize variability of results, particularly concerning biochemical responses, although considering that this experimental strategy implies a reduction of genetic and thus populational representativeness. The selected brood stock intends to represent fish that hatch in the end of the winter/ beginning of spring (March-April), when water temperatures are around $17{ }^{\circ} \mathrm{C}$ in the west of Portugal (Portuguese Metereological Institute database; Mohid water modelling system database-www.mohid.com). Specimens were transported to the laboratory in an aerated 500-1 tank with constant monitoring of temperature, dissolved oxygen and $\mathrm{pH}$. Fish were kept in quarantine (environmental conditions: $19 \pm 2{ }^{\circ} \mathrm{C}$; natural photoperiod and natural seawater; $0.9 \mathrm{~g} \mathrm{l}^{-1}$ fish/tank ratio) for 1 week before the acclimation period to test conditions. Temperature was progressively raised $\left(1^{\circ} \mathrm{C}\right.$ per day until $25^{\circ} \mathrm{C}$ ) to limit fish acute thermal stress.

\section{Effects of Temperature on D. labrax Juveniles}

\section{Bioassay}

To assess the effects of temperature on seabass juveniles, fish were maintained for 30 days at different environmental temperatures: $18 \pm 0.16$ and $25 \pm 0.53{ }^{\circ} \mathrm{C}$ water temperatures, in different acclimatized rooms. These two temperatures are within seabass thermal optimal range and are expected to occur in northwest European estuaries and coastal areas from the end of the spring $\left(18^{\circ} \mathrm{C}\right)$ until the end of the summer $\left(25^{\circ} \mathrm{C}\right.$ ) (Portuguese Metereological Institute database; Mohid water modelling system database-www.mohid.com).

Ten fish per thermal condition were maintained in 200-1 tanks $\left(<0.5 \mathrm{~g} \mathrm{l}^{-1}\right.$ fish/tank ratio) with aerated natural seawater chemically and biologically filtered during the entire period of the bioassay (30 days). Except for the different temperatures, fish were maintained at similar conditions, including 14:10 h (light/dark) photoperiod and being fed 3 times per week with commercial pellets. Water temperatures were daily monitored to certify experimental temperatures. Partial water renewals were made every week, and abiotic parameters [salinity (35 $\left.\mathrm{g}^{-1}\right)$, dissolved oxygen $\left(>7.8 \mathrm{mg} \mathrm{l}^{-1}\right), \mathrm{pH}(8 \pm 0.8)$, phosphate $\left(<1.5 \mathrm{mg} \mathrm{l}^{-1}\right)$, ammonium $\left(<1 \mathrm{mg} \mathrm{l}^{-1}\right)$, nitrates $\left(<2.5 \mathrm{mg} \mathrm{l}^{-1}\right)$ and nitrites $\left.\left(<0.5 \mathrm{mg} \mathrm{l}^{-1}\right)\right]$ were monitored at least once per week for test validation purposes. Mortality and external signs of debility or sickness, like alterations of fish normal behaviour, were also monitored during the bioassay.

\section{Swimming Velocity}

After 30 days, fish from each experimental condition were used to assess the effects of temperature on swimming performance using a swimming behaviour device system shown in Fig. 1. Fish were placed individually in the starting position of the 4-m-long track race (12-cm diameter) and allowed to swim against a constant countercurrent flow $\left(161 \mathrm{~min}^{-1}\right)$ that incites fish natural swimming (Pickett and Pawson 1994). Healthy fish are expected to instantly react to the water flow stimuli and swim fast, reaching the end of the track race $(4 \mathrm{~m})$ in few seconds. Fish subjected to any kind of stress show incapacity to normally react to the water flow stimuli, either by taking longer time to reach the end of the track or stop moving forward in some point of the track keeping in that same position (Gravato and Guilhermino 2009; Almeida et al. 2010; Almeida et al. 2012b). Each fish is individually subjected to just one swimming trial after which returns to the respective experimental tank. Individual swimming velocity was calculated from the equation:

$\mathrm{SV}=$ covered distance/swimming time

where SV is the swimming velocity $(\mathrm{m} / \mathrm{s})$; covered distance (m) is the distance that fish was able to cover in the race track while swimming against the water flow; and the swimming time (s) is the time that fish took to cover that distance, being able to swim forward against the water flow. 


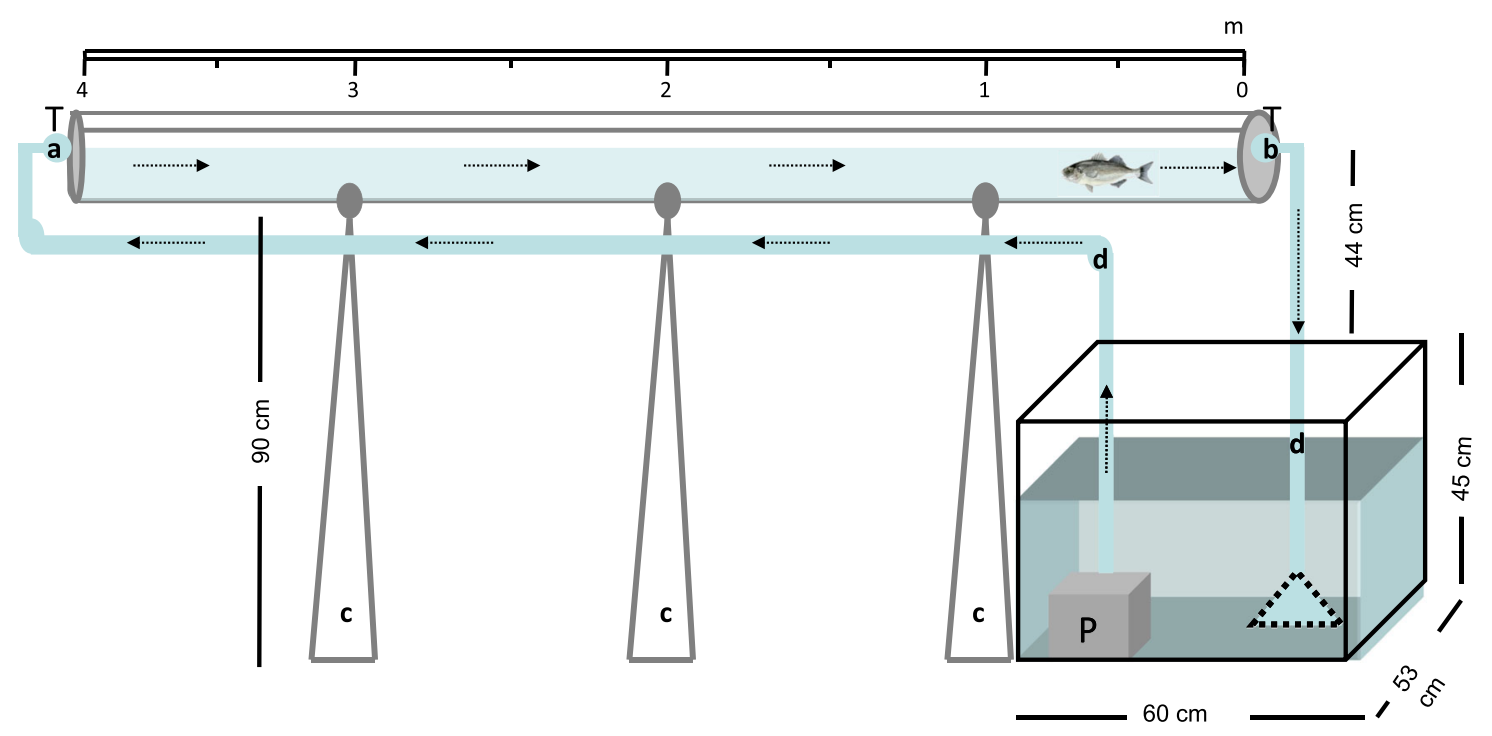

Fig. 1 Behaviour device used to assess the swimming performance of fish composed of a 4-m-long acrylic transparent flume, opened on the top and supported by three metal structures (c). The water is driven from the pool through the system with a water pump (P) via connection hoses (d),

\section{Morphometric Parameters and Tissue Preparation}

After the swimming test, fish were allowed to rest for $2 \mathrm{~h}$ in their original experimental tanks to stabilize metabolic rates, preventing biomarker response interference (Almeida et al. 2010; Almeida et al. 2012a; Almeida et al. 2012b). After $2 \mathrm{~h}$, individual body weight $\left(18{ }^{\circ} \mathrm{C}: 5.55 \pm 0.6 \mathrm{~g} ; 25^{\circ} \mathrm{C}: 6.16 \pm\right.$ $0.6 \mathrm{~g})$ and standard length $\left(18^{\circ} \mathrm{C}: 6.48 \pm 0.4 \mathrm{~cm} ; 25^{\circ} \mathrm{C}: 7.07 \pm\right.$ $0.5 \mathrm{~cm}$ ) were recorded, and fish were immediately euthanized by decapitation. Brain, liver and muscle were immediately isolated on ice and stored at $-80^{\circ} \mathrm{C}$ until further analysis.

\section{Biomarkers}

Individual livers were homogenized $\left(1: 10 \mathrm{~g} \mathrm{wt}^{-1}\right)$ in $\mathrm{K}$ phosphate buffer $(\mathrm{pH} 7.4,0.1 \mathrm{M})$ on ice using an Ystral GmbH d-7801 homogenizer (Dottingen, Germany). Part of this homogenate was separated to determine the extent of endogenous lipid peroxidation (LPO) by measuring the thiobarbituric acid reactive species (TBARS) (Ohkawa et al. 1979; Bird and Draper 1984) and preventing artifactual lipid oxidation by adding $0.2 \mathrm{mM}$ butylhydroxytoluene (BHT) (Torres et al. 2002). Reaction components per $0.2 \mathrm{ml}$ of liver homogenate were $1 \mathrm{ml}$ of $12 \%$ trichloroacetic acid, $0.8 \mathrm{ml}$ of $60 \mathrm{mM}$ Tris- $\mathrm{HCl} \mathrm{pH} 7.4$ with $0.1 \mathrm{mM}$ DTPA and $1 \mathrm{ml}$ of $0.73 \%$ thiobarbituric acid. After incubation in a bath during $60 \mathrm{~min}$ at $100{ }^{\circ} \mathrm{C}$ and further centrifugation at $12,000 \mathrm{~g}$ for $5 \mathrm{~min}, \mathrm{LPO}$ levels were determined in the collected supernatant at $535 \mathrm{~nm}$ in a Jasco V-630 spectrophotometer (Tokyo, Japan) and expressed in nmol TBARS per $\mathrm{g}$ of wet weight (wt). The remaining liver homogenate was centrifuged at and the water flux is controlled by two valves at both sides of the tube (a,b). Arrows represent water flow direction, and fish indicates both starting point position and swimming direction in the countercurrent system

$10,000 \mathrm{~g}$ for $20 \mathrm{~min}$ at $4{ }^{\circ} \mathrm{C}$, and the resultant postmitochondrial supernatant (PMS) was isolated and used for determination of glutathione peroxidase (GPx), glutathione reductase (GR), catalase (CAT) and superoxide dismutase (SOD) activities.

GPx activity was determined by monitoring the decrease of nicotinamide adenine dinucleotide phosphate (NADPH) at $340 \mathrm{~nm}$ using $\mathrm{H}_{2} \mathrm{O}_{2}$ as a substrate (Flohe and Gunzler 1984). Reaction components per $0.04 \mathrm{ml}$ of liver PMS were $0.840 \mathrm{ml}$ of K-phosphate buffer $0.05 \mathrm{M} \mathrm{pH} 7.0$ with $1 \mathrm{mM}$ of EDTA, $1 \mathrm{mM}$ of sodium azide and $1 \mathrm{U} / \mathrm{ml}$ of GR; $0.05 \mathrm{ml}$ of $4 \mathrm{mM}$ GSH; $0.05 \mathrm{ml}$ of NADPH $0.8 \mathrm{mM}$ and $0.01 \mathrm{ml}$ of $0.05 \mathrm{M} \mathrm{H}_{2} \mathrm{O}_{2}$. Enzymatic activity was determined in a Jasco V-630 spectrophotometer (Tokyo, Japan) at $340 \mathrm{~nm}$ during $1 \mathrm{~min}$ at $25^{\circ} \mathrm{C}$.

GR activity was determined from the decrease of NADPH resulting from the reduction of GSSG to GSH with the simultaneous oxidation of NADPH to $\mathrm{NADP}^{+}$(Carlberg and Mannervik 1985) at $340 \mathrm{~nm}$ in a Jasco V-630 spectrophotometer (Tokyo, Japan) for $1 \mathrm{~min}$ at $25^{\circ} \mathrm{C}$. In an optical glass cuvette, $0.950 \mathrm{ml}$ of the reaction buffer including $2.5 \mathrm{mM}$ NADPH, $20 \mathrm{mM} \mathrm{GSSG}$ and $6 \mathrm{mM}$ DTPA in K-phosphate buffer $0.05 \mathrm{M} \mathrm{pH} 7.0$ was added to $0.05 \mathrm{ml}$ of liver PMS.

CAT activity was determined by measuring the $\mathrm{H}_{2} \mathrm{O}_{2}$ consumption at $240 \mathrm{~nm}$ (Clairborne 1985) at $25^{\circ} \mathrm{C}$ for $30 \mathrm{~s}$ in a Jasco V-630 spectrophotometer (Tokyo, Japan) by adding $0.950 \mathrm{ml}$ of K-phosphate buffer $0.05 \mathrm{M} \mathrm{pH} 7.0$ and $0.5 \mathrm{ml}$ of a $\mathrm{H}_{2} \mathrm{O}_{2} 0.05 \mathrm{M}$ solution to $0.005 \mathrm{ml}$ of liver PMS.

SOD activity was determined by the reduction of cytochrome $c$ in the presence of superoxide radicals and expressed as the amount of enzyme required to inhibit in $50 \%$ the rate of 
reduction of cytochrome $c$ (Flohe and Otting 1984) adapted to microplate (Lima et al. 2007). Liver PMS $(0.5 \mathrm{ml})$ with $0.25 \mathrm{mg} \mathrm{ml}^{-1}$ protein content was added to $0.2 \mathrm{ml}$ of the reaction solution $(10 \mathrm{ml}$ of xanthine $0.7 \mathrm{mM}$ in a $\mathrm{NaOH}$ $1 \mathrm{mM}$ solution $+100 \mathrm{ml}$ of a $0.03 \mathrm{mM}$ cytochrome $c$ in $50 \mathrm{mM} \mathrm{Na} 2$-phosphate buffer $\mathrm{pH} 7.8$ solution containing $1 \mathrm{mM}$ of Na-EDTA); the change in optical density was recorded in a microplate reader Bio Tek Power Wave 340 (Winooski, Vermont, USA) at $550 \mathrm{~nm}$ at $25^{\circ} \mathrm{C}$ for $3 \mathrm{~min}$.

Different portions of the dorsal muscle $(0.1-0.2 \mathrm{~g})$ were used to measure IDH and LDH activities. Preparation of samples for IDH activity included homogenization in tris (hydroxymethyl)aminomethane buffer ( $\mathrm{pH} 7.8,50 \mathrm{mM}$ ), followed by centrifugation at 3,300g for $3 \mathrm{~min}$ at $4{ }^{\circ} \mathrm{C}$. IDH activity was determined from the increase in NADPH at $340 \mathrm{~nm}$ (Ellis and Goldberg 1971) in a microplate (Lima et al. 2007). Muscle supernatant ( $0.05 \mathrm{ml}$ of supernatant standardized at $1 \mathrm{mg} \mathrm{ml}^{-1}$ of protein) was added to $0.2 \mathrm{ml}$ of the reaction solution $(40 \mathrm{ml}$ of $50 \mathrm{mM}$ tris buffer $\mathrm{pH} 7.8,15 \mathrm{ml}$ of $2 \mathrm{mM}$ manganese(II) chloride, $15 \mathrm{ml}$ of $7 \mathrm{mM}$ DL-isocitric acid) plus $0.05 \mathrm{ml}$ of $0.5 \mathrm{mM} \mathrm{NADP}^{+}$. The enzymatic activity was determined at $340 \mathrm{~nm}$ in a Bio Tek Power Wave 340 microplate reader (Winooski, Vermont, USA) for $3 \mathrm{~min}$ at $25^{\circ} \mathrm{C}$.

For LDH determinations, samples were homogenized in $1 \mathrm{ml}$ of ice-cold Tris/ $\mathrm{NaCl}$ buffer $\mathrm{pH} 7.2$ (Tris $81.3 \mathrm{mM} ; \mathrm{NaCl}$ $203.3 \mathrm{mM}$ ) and centrifuged at $3,300 \mathrm{~g}$ for $3 \mathrm{~min}$ at $4{ }^{\circ} \mathrm{C}$ after three frozen/unfrozen cycles. LDH activity was determined by measuring the amount of pyruvate consumed due to NADH oxidation at $340 \mathrm{~nm}$ (Vassault 1983) adapted to microplate (Diamantino et al. 2001). The reaction mixture contained $0.01 \mathrm{ml}$ of muscle supernatant (standardized to $1 \mathrm{mg} \mathrm{ml}^{-1}$ protein), $0.25 \mathrm{ml}$ of a $0.25 \mathrm{mM}$ NADH solution in Tris $/ \mathrm{NaCl}$ buffer and $0.04 \mathrm{ml}$ of a $12 \mathrm{mM}$ pyruvate solution in Tris/ $\mathrm{NaCl}$ buffer. The enzymatic activity was then determined at $340 \mathrm{~nm}$ in a Bio Tek Power Wave 340 microplate reader (Winooski, Vermont, USA) for $2.5 \mathrm{~min}$ at $25^{\circ} \mathrm{C}$. All enzymatic activities were expressed as the amount of substrate hydrolysed per minute per milligram of protein (exceptions previously stated). Protein determination of samples was performed in triplicate using bovine $\gamma$-globulins (Sigma-Aldrich, USA) as standard (Bradford 1976) in a microplate as previously adapted (Frasco and Guilhermino 2002): $0.25 \mathrm{ml}$ of the Bradford reagent (BioRad), diluted 5 times in ultrapure water, was added to $0.01 \mathrm{ml}$ of fish tissue; after an incubation period of $15 \mathrm{~min}$ at $25^{\circ} \mathrm{C}$, the absorbance was read at $600 \mathrm{~nm}$ in a Bio Tek Power Wave 340 microplate reader (Winooski, Vermont, USA).

For cholinesterases activity determination, the whole brain and a portion of the dorsal muscle $(0.1-0.2 \mathrm{~g})$ were homogenized in $1 \mathrm{ml}$ of ice-cold K-phosphate buffer ( $\mathrm{pH} 7.2,0.1 \mathrm{M}$ ) and centrifuged at $3,300 \mathrm{~g}$ at $4{ }^{\circ} \mathrm{C}$ for $3 \mathrm{~min}$. The supernatants were used to measure brain and muscle $\mathrm{ChE}$ by the Ellman technique (Ellman et al. 1961) adapted to microplate (Guilhermino et al. 1996). In each microplate well, $0.25 \mathrm{ml}$ of the reaction solution including $30 \mathrm{ml}$ of phosphate buffer (ph 7.2, $0.1 \mathrm{M}$ ), $1 \mathrm{ml}$ of reagent dithiobisnitrobenzoate $10 \mathrm{mM}$ (20 mM acid dithiobisnitrobenzoate and $18 \mathrm{mM}$ sodium hydrogen carbonate in $0.1 \mathrm{M} \mathrm{K}$-phosphate buffer, $\mathrm{pH}$ 7.2) and $0.2 \mathrm{ml}$ of acetylcholine iodide $0.075 \mathrm{M}$ in ultra-pure water were added to $0.05 \mathrm{ml}$ of fish brain or muscle homogenate supernatant after protein standardization to $0.5 \mathrm{mg} \mathrm{ml}^{-1}$. The absorbance was determined at $412 \mathrm{~nm}$ in a microplate reader Bio Tek Power Wave 340 (Winooski, Vermont, USA) at $25^{\circ} \mathrm{C}$ for $5 \mathrm{~min}$. Previous characterization of D. labrax ChEs in brain and muscle revealed that brain contains mainly acetilcholinesterase (AChE), while muscle has both AChE and pseudocholinesterase (Varò et al. 2003). Thus, despite acetylthiocholine was used as substrate in both assays, the enzymatic activity determined in brain and muscle will be further indicated as $\mathrm{AChE}$ and $\mathrm{ChE}$ activity, respectively.

\section{Data Analysis}

All data were first analysed by Kolmogorov-Smirnov and Levene's test to assess the normality and equality of variance, respectively, and appropriate data transformations were used when assumptions of normality or equality of variance were not fulfilled. Student's $t$ test was used to compare the means of pairs of corresponding treatments at distinct temperatures (18 and $25^{\circ} \mathrm{C}$ ) (Zar 1999). Significance level was $p<0.05$. PASW Statistics 18.0 package was used for statistical analysis.

\section{Results}

\section{Test Validation and General Effects}

During acclimation to different temperatures, $5 \%$ of mortality was recorded in the first 2 weeks at $25{ }^{\circ} \mathrm{C}$ with no further mortality in the remaining period. No mortality was observed at $18^{\circ} \mathrm{C}$. The bioassays were considered valid since the mortality was less than $10 \%$. In addition, mean levels of water quality parameters were adequate for fish at both temperatures, and water temperature variation was $0.16^{\circ} \mathrm{C}$ at $18{ }^{\circ} \mathrm{C}$ and $0.53{ }^{\circ} \mathrm{C}$ at $25{ }^{\circ} \mathrm{C}$. Comparative to animals maintained at $18{ }^{\circ} \mathrm{C}$, fish maintained at $25{ }^{\circ} \mathrm{C}$ exhibited changes in normal behaviour, some lethargy, swimming discoordination, lack of typical schooling pattern and lack of active swimming under the expectance of being fed. These are considered common behaviours presented by fish in captivity and were observed in fish maintained at $18{ }^{\circ} \mathrm{C}$ during the entire period of the bioassay.

\section{Effects of Temperature on Fish Swimming Velocity}

Concerning the swimming test performed after 30 days of maintenance at 18 and $25^{\circ} \mathrm{C}$, swimming velocity was significantly decreased $\left(t_{(18)}=3.028, p=0.007\right)$ in fish maintained at 
the higher temperature relative to those maintained at $18{ }^{\circ} \mathrm{C}$ (Fig. 2).

Effects of Temperature on Fish Health Status

Regarding antioxidant defences (Fig. 3), CAT and GPx activities were significantly higher $(+74$ and $+41 \%$, respectively) in fish maintained at $25^{\circ} \mathrm{C}$ in relation to the values determined in fish maintained at $18{ }^{\circ} \mathrm{C}$ (CAT: $t_{(18)}=-3.378, p=0.003$; GPx: $t_{(17)}=-2.164, p=0.045$ ), and no significant differences were found in any of the other parameters analysed (Table 1) (SOD: $t_{(16)}=-1.351, p=0.195$; GR: $t_{(16)}=-1.071, p=0.300$ ). At $25{ }^{\circ} \mathrm{C}$, fish had significant higher LPO levels $\left(t_{(18)}=\right.$ $-3.426, p=0.003)$, more $89 \%$ than fish maintained at $18^{\circ} \mathrm{C}$.

Concerning energetic metabolism parameters, IDH activity was significantly increased $(+40.5 \%)$ in fish maintained at $25^{\circ} \mathrm{C}\left(t_{(18)}=-2.168, p=0.044\right)$ compared to the activity determined in fish maintained at $18{ }^{\circ} \mathrm{C}$. No significant differences in LDH activity were found $\left(t_{(18)}=0.422, p=0.678\right)$ (Fig. 4).

Brain $\mathrm{AChE}$ and muscle $\mathrm{ChE}$ activities were induced $\left(t_{(18)}=-3.176, p=0.005 ; t_{(16)}=-3.488, p=0.003\right)$ in fish maintained at $25^{\circ} \mathrm{C}$ with 19 and $18 \%$ of induction relative to fish maintained at $18{ }^{\circ} \mathrm{C}$ (Fig. 5).

\section{Discussion}

\section{Effects of Temperature on Fish Swimming Velocity}

A decrease in swimming velocity was observed in fish maintained at $25^{\circ} \mathrm{C}$ relative to those maintained at $18^{\circ} \mathrm{C}$. Previous studies on the effects of temperature on the seabass swimming performance also showed a decreasing tendency for temperatures higher than $24{ }^{\circ} \mathrm{C}$ (Koumoundouros et al. 2002; Koumoundouros et al. 2009). In addition, seabass maximum swimming speed was found at temperatures between 22 and

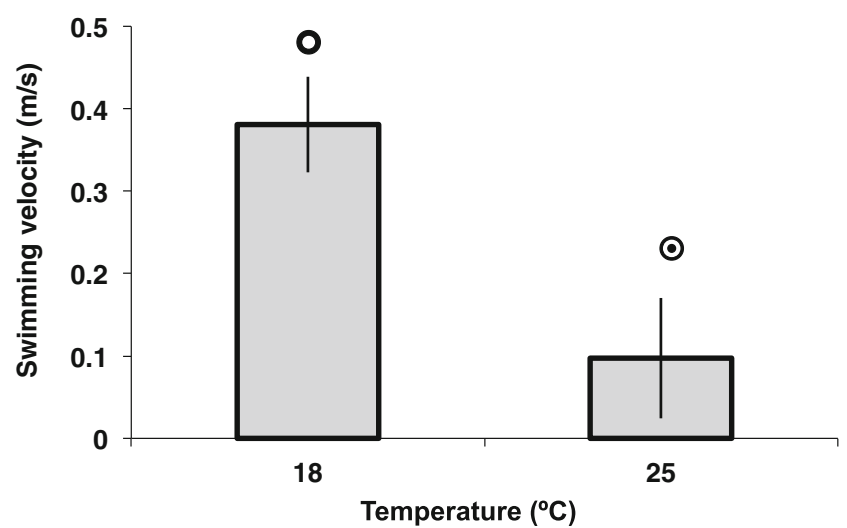

Fig. 2 Swimming velocity of Dicentrarchus labrax after 30 days at 18 and $25{ }^{\circ} \mathrm{C}$. Values are the mean of 10 fish per treatment with the corresponding standard error bars. Different symbols indicate statistical significant differences $(p<0.05$, Student's $t$ test $)$
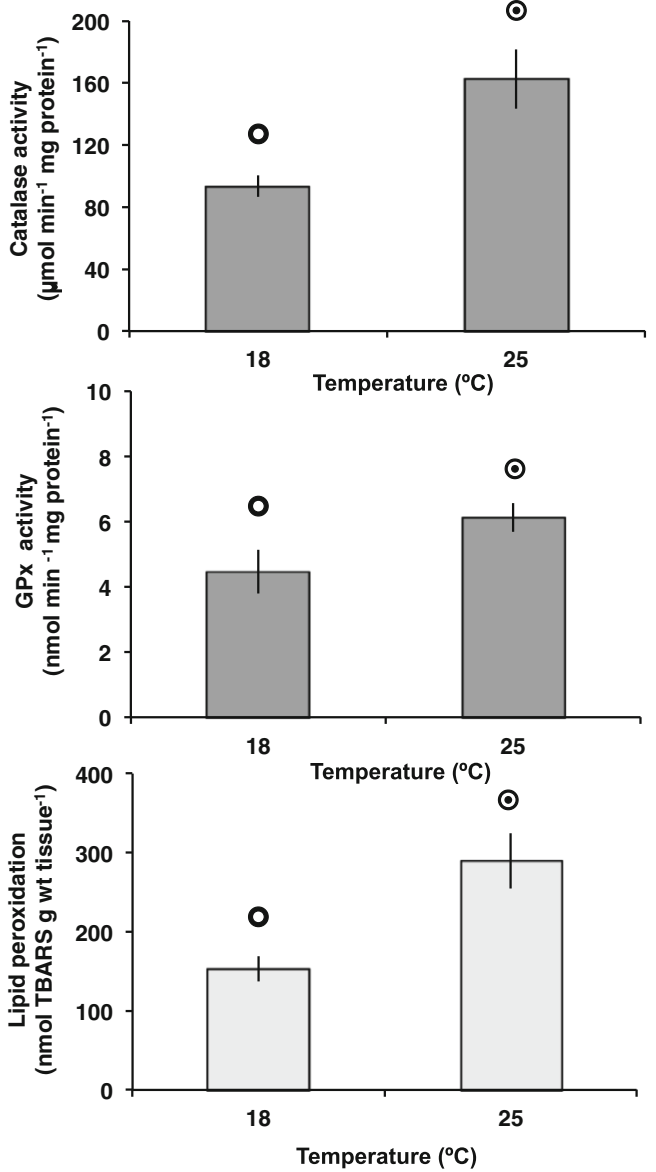

Fig. 3 Liver catalase, glutathione peroxidase activities and lipid peroxidation levels (LPO) of Dicentrarchus labrax after 30 days at 18 and $25^{\circ} \mathrm{C}$. Values are the mean of 10 fish per treatment for catalase and LPO and 9-10 fish for glutathione peroxidase with the corresponding standard error bars. Different symbols indicate statistical significant differences $(p<0.05$, Student's $t$ test $)$

$24^{\circ} \mathrm{C}$ (Claireaux et al. 2006). In this study, at $25^{\circ} \mathrm{C}$, fish also showed some qualitative signs of debility shown by a loss of typical schooling behaviour and swimming desynchronization. The reduction of the swimming velocity found in fish exposed to $25{ }^{\circ} \mathrm{C}$ may be a strategy to reduce

Table 1 Glutathione reductase (GR) and superoxide dismutase (SOD) antioxidant activities in the liver of Dicentrarchus labrax after 30 days at 18 and $25^{\circ} \mathrm{C}$

\begin{tabular}{llrr}
\hline Function & Biomarker & \multicolumn{2}{l}{ Temperature $\left({ }^{\circ} \mathrm{C}\right)$} \\
\cline { 3 - 4 } & & 18 & \multicolumn{1}{c}{25} \\
\hline Liver antioxidant defences & GR & $7.5 \pm 0.77$ & $8.5 \pm 0.52$ \\
& SOD & $13.4 \pm 0.59$ & $18.1 \pm 2.90$ \\
\hline
\end{tabular}

Values are the mean \pm standard error of ten fish. Units are nmol $\mathrm{min}^{-1} \mathrm{mg}$ protein $^{-1}$ for glutathione reductase (GR) activity and $\mathrm{U} \mathrm{mg} \mathrm{protein^{-1 }}$ for superoxide dismutase (SOD) activity 


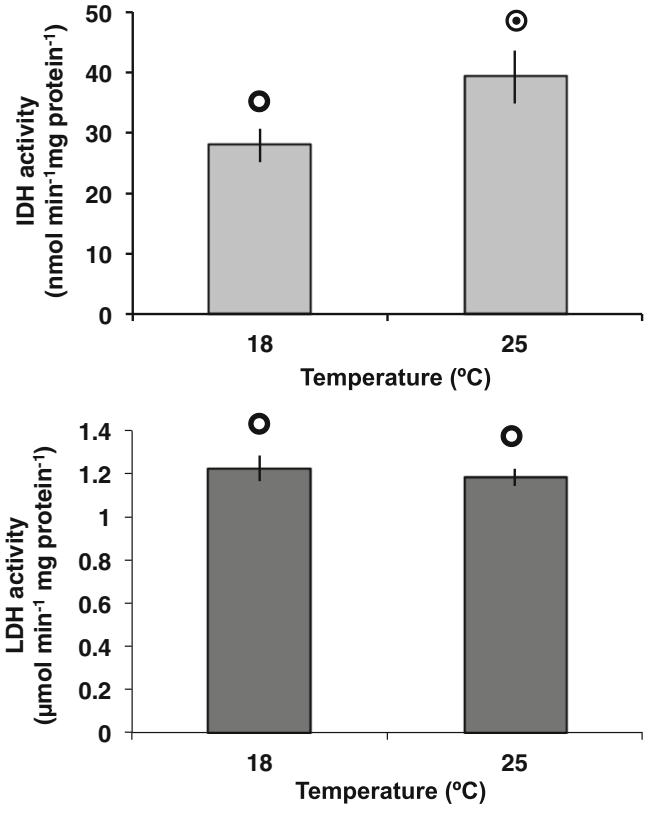

Fig. 4 Muscle isocitrate dehydrogenase (IDH) and lactate dehydrogenase (LDH) activities of Dicentrarchus labrax after 30 days at 18 and $25^{\circ} \mathrm{C}$. Values are the mean of 10 fish per treatment with the corresponding standard error bars. Different symbols indicate statistical significant differences ( $p<0.05$, Student's $t$ test)

energetic expenditures recurrent from physical activity, which might be essential to cope maintenance energetic costs and recycling waste products (Pörtner et al. 2006), among other reasons that might be related with other simultaneous physiological alterations. Previous studies regarding thermal responses in fish also reported swimming disturbances with increasing temperatures, attributed to energetic constraints (Taylor et al. 1997; Breau et al. 2011). In natural conditions, swimming velocity impairment may have serious consequences for population fitness as it may interfere with the most important fish activities, such as prey capture and

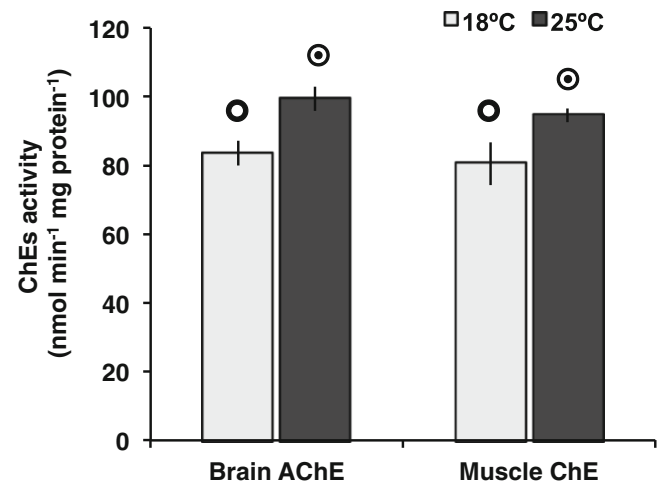

Fig. 5 Brain acetylcholinesterase and muscle cholinesterase activities of Dicentrarchus labrax after 30 days at 18 and $25^{\circ} \mathrm{C}$. Values are the mean of 10 fish per treatment with the corresponding standard error bars. Different symbols indicate statistical significant differences ( $p<0.05$, Student's $t$ test) predator avoidance (Moyle and Cech 2003). Loss of schooling behaviour observed in this study may also result from swimming impairment since synchronized swimming might be compromised. In the wild, schools are survival strategies that play a crucial role as antipredator tactic but also in foraging and spawning activities (Pitcher and Parrish 1993). Thus, decreased swimming capacities may have direct effects on population intrinsic growth rate, increasing mortality by predation, reducing fish growth by difficulties in prey capture and influencing a successful reproduction cycle.

\section{Effects of Temperature on Fish Health Status}

Results from the present study also show physiological alterations on different important functions in fish exposed to $25^{\circ} \mathrm{C}$. Increased activities of antioxidant enzymes (namely CAT and GPx) observed in fish maintained at $25^{\circ} \mathrm{C}$ compared to seabass kept at $18^{\circ} \mathrm{C}$, suggest that higher temperature led to an overproduction of ROS, and that fish tried to cope with it by inducing these two antioxidant mechanisms. The concomitant increase in LPO levels observed in seabass at $25{ }^{\circ} \mathrm{C}$ indicates that CAT and GPx activity induction was not sufficient to efficiently overcome the induced oxidative stress measured as lipid damage. These findings are in good agreement with the results of previous studies using other species (Zhang et al. 2003; An and Choi 2010), including fish (Lushchak and Bagnyukova 2006b) and also in seabass (Roche and Bogé 1996). Other recent studies found an increase in LPO and CAT activities in seabass juveniles exposed to $28^{\circ} \mathrm{C}$ (Vinagre et al. 2012a). The increased activities of antioxidant enzymes observed in this study also support the hypothesis that decreased swimming velocity facing temperature increase is caused by increased oxygen consumption and energetic requirements for elimination of toxic metabolites, detoxication and tissue reparation, resultant from ROS production and oxidative damage (Lushchak and Bagnyukova 2006a; Aslanidi et al. 2008).

Seabass maintained at $25^{\circ} \mathrm{C}$ also showed an increased IDH activity compared to fish kept at $18{ }^{\circ} \mathrm{C}$. IDH is an important enzyme both in the aerobic pathway of cellular energy production, where it catalyses one of the key steps of the citric acid cycle, and also in antioxidant defences, where it is crucial for the regeneration of NADPH necessary for glutathione conjugation pathways (Jo et al. 2001; Lee et al. 2002). Thus, increased IDH activity in fish maintained at $25^{\circ} \mathrm{C}$ suggests (i) an increase of energy production through the aerobic pathway to cope with ROS production, (ii) an increase of antioxidant defences that require NADPH or (iii) both processes. As a consequence of extra energetic requirements to face thermal disturbances, energy available to other functions might be reduced (Angilletta 2009). Therefore, decreased swimming velocity found in fish maintained at $25{ }^{\circ} \mathrm{C}$ may be also due, at least in part, to the need of allocating energy to face thermal alterations in detriment of swimming activity. Increased 
metabolic rates were also found in previous studies with seabass juveniles exposed to temperature increase (Vinagre et al. 2012c). However, as previously stated, the metabolic rates of ectotherms are naturally dependent on environmental temperatures, and intensification of respiration rates with consequent ROS production and antioxidant reparation is expected in their adaptative process to a new temperature (Lushchak and Bagnyukova 2006b) and thus may occur in natural populations subjected to temperature variation.

Fish kept at $25{ }^{\circ} \mathrm{C}$ also showed signs of motor discoordination and increased activities of both brain $\mathrm{AChE}$ and muscle ChE enzymes. This is compliant with the findings previously reported for other species (Hussein et al. 1983; Mukhopadhyay and Poddar 1990). Considering that in fish species like D. labrax, higher environmental temperature leads to an increase in internal body temperature and also that increased levels of LPO were observed, it can be hypothesized that (i) increased lipid fluidity and/or lipid peroxidation occurred in cell membranes of cholinergic synapses (both in central and peripheral nervous systems) causing an increased release of the neurotransmitter acetylcholine, (ii) AChE activity is increased to degrade the excess of the neurotransmitter present in the synaptic cleft and (iii) the increase of AChE activity is not sufficient to avoid the continuous overstimulation of acetylcholine receptors in post-synaptic membranes. In any case, cholinergic neurotransmission is induced, and fish show signs of motor discoordination, decreased swimming capability and apparent loss of typical behaviours, such as schooling. Induced oxidative stress is also described as responsible for an increase in cholinesterase activity in neuronal models (Melo et al. 2003), and an increase in synaptic neurotransmission caused by increased cell membrane fluidity is also related with swimming disturbances in goldfish (C. auratus) exposed to heat stress (Szabo et al. 2008). Recent findings indicate an increase in the combined expression of two heat shock proteins (Hsc/Hsp 70) in muscle of juvenile seabass exposed to 24 and $28{ }^{\circ} \mathrm{C}$ (Vinagre et al. 2012b), pointing out that molecular processes of reparation are occurring at these temperatures and also corroborating the hypothesis of induced thermal stress responses at $24{ }^{\circ} \mathrm{C}$ or higher in seabass juveniles.

Considering the overall results of the present study, a temperature of $25{ }^{\circ} \mathrm{C}$ caused physiological and behavioural alterations in seabass that can be related as above hypothesized and discussed, and that are more frequent in real scenarios within D. labrax geographical distribution. In natural conditions, $25{ }^{\circ} \mathrm{C}$ is within the optimum thermal range for sea bass (Barnabé 1990); however, it is also the limit temperature of maximum abundance of juveniles in northwest European estuaries (Cabral and Costa 2001). However, as a consequence of global warming and occasional extreme events that are expected to occur (IPCC 2007), seabass juveniles may be subjected to higher temperatures (even higher than $25^{\circ} \mathrm{C}$ ) more frequently and for longer periods of time. In this case, the biological consequences of increasing temperatures might be aggravated, as the impairment of such an important behaviour as swimming velocity may lead to severe implications in vital activities of seabass (foraging, escape from predators, mating, schooling), affecting recruitment, reproduction and survival and, thus, limiting the growth rate of D. labrax population (Godin 1997; Moyle and Cech 2003). These populational constraints may also have repercussions on ecosystem functioning as D. labrax plays important roles in both estuarine and coastal food chains, in distinct developmental stages, and this habitat shift might also be compromised.

\section{Implications for Environmental Monitoring}

All the effects observed in this study, associated to the effects of temperature on fish health status, showed the potential effects of temperature increase (global warming) on D. labrax basic functions, essential for well performing in the wild. These findings also indicate that temperature per se may act as a confounding factor on the selected endpoint responses. As the endpoints employed in this study (biomarkers) are now commonly used in ecological quality assessment studies (Thain et al. 2008; Fossi et al. 2012) and are recommended for environmental risk assessment (van der Oost et al. 2003), the effects caused only by temperature increase must be regarded as they may potentially influence the interpretation of actual risk by directly altering organism responses. This becomes particularly important in the current context dealing with the urgent concern to improve the quality of the marine environment in compliance with the objectives of the Water Framework Directive (WFD 2000/60/EC) (European Commission 2000) and the Marine Strategy Framework Directive (MSFD 2008/56/EC) (European Commission 2008). Most of the descriptors considered in these directives, mainly regarding organism dynamics and responses, can be dependent on temperature (as shown in this study). Both seasonal, latitudinal variations and those resulting from global warming events are included, and these scenarios should be taken into account in ecological quality assessment studies, marine environmental monitoring and ecological risk assessment. Furthermore, in addition to the effects that temperature may induce solely, it may also interfere with the effects of other stressors on organisms, such as chemical environmental contaminants. For example, temperature may modify the toxicity of chemicals through toxicological interactions, by interfering with chemicals bioavailability; by altering the fate of the toxicants in the organism (e.g. decreasing excretion of toxic metabolites); by increasing the susceptibility of organisms to chemical stress, through abiotic and biotic changes in their habitat; among other possibilities (Schiedek et al. 2007; Noyes et al. 2009). This also highlights the need of more research on the combined effects of temperature and chemical interaction 
on marine species in both laboratory conditions and field studies.

\section{Conclusions}

This study applied a multiparameter approach including physiological and behavioural parameters to evaluate the effects of temperature increase on a poikilothermic species (D. labrax) with considerable ecological and economical importance. Seabass maintained at $25{ }^{\circ} \mathrm{C}$ showed increased activities of antioxidant enzymes indicating overproduction of ROS; increased lipid peroxidation levels indicating lipid damage; increased activity of IDH, an enzyme involved in the aerobic production of energy and in oxidative stress defences, suggesting increased energy demands to face thermic demands; and increased levels of $\mathrm{ChE}$ activity in both brain and muscle, along with discoordination, lost of typical behaviour and decreased swimming activity. Considering the primary effects of global warming in estuaries of temperate regions, especially in late spring and summer, where the main reproduction and recruitment periods of $D$. labrax occur, the findings of this study raise concern on seabass wild populations fitness. An important output of this study is the importance of an integrated multiparameter approach including several endpoints at different levels of biological organization and representing different important functions in the assessment and interpretation of the effects of thermal variations in D. labrax. Findings also highlight the need of more research on the effects of temperature, and combined effects with chemicals on marine species in both laboratory conditions and field studies (e.g. long-term monitoring) and of considering temperature in ecological quality and ecological risk assessments, particularly in estuaries and other highly shifting marine environments.

Acknowledgments This study was done in the scope of the project 'RAMOCS - Implementation of Risk Assessment Methodologies for Oil and Chemical Spills in the European Marine Environment', funded by the Portuguese Foundation for the Science and Technology (FCT) and FEDER funds (ERA-AMPERA/0001/2007), in the framework of the EU ERA-NET AMPERA (ERAC-CT2005-016165, 6th EU Framework Program). This research was partially supported by the European Regional Development Fund (ERDF) through the COMPETE - Operational Competitiveness Programme and national funds through FCT-Foundation for Science and Technology, under the project 'PEst-C/MAR/ LA0015/2013'. Joana R. Almeida had a PhD grant from FCT (SFRH/BD/40843/2007) supported with European social funds and funds of Portuguese MCTES (POPH-QREN-Tipology 4.2).

\section{References}

Almeida, J.R., C. Oliveira, C. Gravato, and L. Guilhermino. 2010. Linking behavioural alterations with biomarkers responses in the European seabass Dicentrarchus labrax L. exposed to the organophosphate pesticide fenitrothion. Ecotoxicology (London, England) 19: 1369-1381.

Almeida, J.R., C. Gravato, and L. Guilhermino. 2012a. Biological parameters towards polycyclic aromatic hydrocarbons pollution: a study with Dicentrarchus labrax L. exposed to the model compound benzo(a)pyrene. Water Air Soil Poll 223: 4709-4722.

Almeida, J.R., C. Gravato, and L. Guilhermino. 2012b. Challenges in assessing the toxic effects of polycyclic aromatic hydrocarbons to marine organisms: a case study on the acute toxicity of pyrene to the European seabass (Dicentrarchus labrax L.). Chemosphere 86: 926 937.

An, M.I., and C.Y. Choi. 2010. Activity of antioxidant enzymes and physiological responses in ark shell, Scapharca broughtonii, exposed to thermal and osmotic stress: effects on hemolymph and biochemical parameters. Comparative Biochemistry and Physiology. Part B, Biochemistry and Molecular Biology 155: 34-42.

Angilletta, M.J.J. 2009. Thermal adaptation: a theoretical and empirical synthesis. Oxford: Oxford University Press.

Aslanidi, K.B., D.P. Kharakoz, and L.M. Chailakhyan. 2008. Temperature shock and adaptation in fish. Doklady 422: 302-303.

Barnabé, G. 1990. Rearing bass and gilthead bream. In Aquaculture, ed. G. Barnabé, 647-686. New York: Ellis Horwood Books in Aquaculture and Fisheries Support.

Beitinger, T.L., and L.C. Fitzpatrick. 1979. Physiological and ecological correlates of preferred temperature in fish. American Zoologist 19: 319-329.

Beitinger, T.L., W.A. Bennett, and R.W. McCauley. 2000. Temperature tolerances of North American freshwater fishes exposed to dynamic changes in temperature. Environmental Biology of Fishes 58: 237-275.

Bird, R.P., and A.H. Draper. 1984. Comparative studies on different methods of malondyhaldehyde determination. Methods in Enzymology 90: 105-110.

Bradford, M.M. 1976. A rapid and sensitive method for the quantitation of microgram quantities of protein utilizing the principle of proteindye binding. Analytical Biochemistry 72: 248-254.

Breau, C., R.A. Cunjak, and S.J. Peake. 2011. Behaviour during elevated water temperatures: can physiology explain movement of juvenile Atlantic salmon to cool water? Journal of Animal Ecology 80: 844-853.

Cabral, H., and M.J. Costa. 2001. Abundance, feeding ecology and growth of 0-group sea bass, Dicentrarchus labrax, within the nursery areas of the Tagus estuary. Journal of the Marine Biological Association of the United Kingdom 81: 679-682.

Carlberg, I., and B. Mannervik. 1985. Glutathione reductase. Methods in Enzymology 113: 484-490.

Clairborne, A. 1985. Catalase activity. In CRC handbook of methods in oxygen radical research, ed. R.A. Greenwald, 283-284. Boca Raton: CRC.

Claireaux, G., C. Couturier, and A.L. Groison. 2006. Effect of temperature on maximum swimming speed and cost of transport in juvenile European sea bass (Dicentrarchus labrax). The Journal of Experimental Biology 209: 3420-3428.

Diamantino, T.C., E. Almeida, A.M. Soares, and L. Guilhermino. 2001. Lactate dehydrogenase activity as an effect criterion in toxicity tests with Daphnia magna straus. Chemosphere 45: 553-560.

Durrieu de Madron, X., C. Guieu, R. Sempéré, P. Conan, D. Cossa, F. D’Ortenzio, C. Estournel, F. Gazeau, C. Rabouille, L. Stemmann, et al. 2011. Marine ecosystems's responses to climatic and anthropogenic forcings in the Mediterranean. Progress in Oceanography 91: 97-166.

Ellis, G., and D.M. Goldberg. 1971. An improved manual and semiautomatic assay for NADP-dependent isocitrate dehydrogenase activity, with a description of some kinetic properties of human liver and serum enzyme. Clinical Biochemistry 4: 175-185.

Ellman, G.L., A. Burkhalter, and J. Ladou. 1961. A fluorometric method for the determination of hippuric acid. Journal of Laboratory and Clinical Medicine 57: 813-818. 
European Commission. 2000. Directive 2000/60/EC of the European Parliament and of the Council of 23 October 2000, establishing a framework for community action in the field of water policy. Official Journal of the European Union L327: 1-72.

European Commission. 2008. Directive 2008/56/EC of the European Parliament and of the Council of 17 June 2008, establishing a framework for community action in the field of marine environmental policy (Marine Strategy Framework Directive). Official Journal of the European Union L164: 19-40.

Flohe, L., and W.A. Gunzler. 1984. Assays of glutathione peroxidase. Methods in Enzymology 105: 114-121.

Flohe, L., and F. Otting. 1984. Superoxide dismutase assays. Methods in Enzymology 105: 93-104.

Fossi, M.C., S. Casini, I. Caliani, C. Panti, L. Marsili, A. Viarengo, R. Giangreco, G.N. di Sciara, F. Serena, A. Ouerghi, et al. 2012. The role of large marine vertebrates in the assessment of the quality of pelagic marine ecosystems. Marine Environmental Research 77: 156-158.

Frasco, M.F., and L. Guilhermino. 2002. Effects of dimethoate and betanaphthoflavone on selected biomarkers of Poecilia reticulata. Fish Physiology and Biochemistry 26: 149-156.

Fry, F.E.J. 1971. The Effect of environmental factors on the physiology of fish. In Hoar, W.S, ed. D.J. Randall, 1-98. Academic: Fish physiology.

Godin, J.-G.J., 1997. Behavioural ecology of teleost fishes. Oxford University Press New York

Golovanov, V. 2006. The ecological and evolutionary aspects of thermoregulation behavior on fish. Journal of Ichthyology 46: S180-S187.

Gravato, C., and L. Guilhermino. 2009. Effects of benzo(a)pyrene on seabass (Dicentrarchus labrax L.): biomarkers, growth and behavior. Human Ecol Risk Assess 15: 121-137.

Guilhermino, L., M.C. Lopes, A.P. Carvalho, and A. Soares. 1996. Inhibition of acetylcholinesterase activity as effect criterion in acute tests with juvenile Daphnia Magna. Chemosphere 32: 727-738.

Hussein, M.F., M.I. Mohamed, M.F. Selim, and M.A. El Din. 1983. Ambient temperature effects on brain and spinal cord acetylcholinesterase activity of two poikilotherms. Comparative Biochemistry and Physiology. C 75: 357-359.

IPCC, 2007. Climate Change 2007: Synthesis Report. Contribution of Working Groups I, II and III to the Fourth Assessment Report of the Intergovernmental Panel on Climate Change. in: Core Writing Team, P., R.K and Reisinger, A. (Ed.). IPCC, Geneva, Switzerland, p. 104 pp.

Jo, S.H., M.K. Son, H.J. Koh, S.M. Lee, I.H. Song, Y.O. Kim, Y.S. Lee, K.S. Jeong, W.B. Kim, J.W. Park, et al. 2001. Control of mitochondrial redox balance and cellular defense against oxidative damage by mitochondrial NADP+ -dependent isocitrate dehydrogenase. The Journal of biological chemistry 276: 16168-16176.

Koumoundouros, G., D.G. Sfakianakis, P. Divanach, and M. Kentouri. 2002. Effect of temperature on swimming performance of sea bass juveniles. Journal of Fish Biology 60: 923-932.

Koumoundouros, G., C. Ashton, D.G. Sfakianakis, P. Divanach, M. Kentouri, N. Anthwal, and N.C. Stickland. 2009. Thermally induced phenotypic plasticity of swimming performance in European sea bass Dicentrarchus labrax juveniles. Journal of Fish Biology 74: 1309-1322

Lee, S.M., H.J. Koh, D.C. Park, B.J. Song, T.L. Huh, and J.W. Park. 2002. Cytosolic NADP(+)-dependent isocitrate dehydrogenase status modulates oxidative damage to cells. Free Radical Biology and Medicine 32: 1185-1196.

Lima, I., S.M. Moreira, J.R. Osten, A.M. Soares, and L. Guilhermino. 2007. Biochemical responses of the marine mussel Mytilus galloprovincialis to petrochemical environmental contamination along the Northwestern coast of Portugal. Chemosphere 66: 1230-1242.

Limon-Pacheco, J., and M.E. Gonsebatt. 2009. The role of antioxidants and antioxidant-related enzymes in protective responses to environmentally induced oxidative stress. Mutation Research 674: 137-147.
Livingstone, D.R. 2001. Contaminant-stimulated reactive oxygen species production and oxidative damage in aquatic organisms. Marine Pollution Bulletin 42: 656-666.

Lushchak, V.I., and T.V. Bagnyukova. 2006a. Temperature increase results in oxidative stress in goldfish tissues. 1. Indices of oxidative stress. Comparative Biochemistry and Physiology C Toxicol Pharmacol 143: 30-35.

Lushchak, V.I., and T.V. Bagnyukova. 2006b. Temperature increase results in oxidative stress in goldfish tissues. 2. Antioxidant and associated enzymes. Comparative Biochemistry and Physiology $C$ Toxicol Pharmacol 143: 36-41.

Madeira, D., L. Narciso, H.N. Cabral, and C. Vinagre. 2012. Thermal tolerance and potential impacts of climate change on coastal and estuarine organisms. Journal of Sea Research 70: 32-41.

Magnuson, J.J., L.B. Crowder, and P.A. Medvick. 1979. Temperature as an ecological resource. American Zoologist 19: 331-343.

Melo, J.B., P. Agostinho, and C.R. Oliveira. 2003. Involvement of oxidative stress in the enhancement of acetylcholinesterase activity induced by amyloid beta-peptide. Neuroscience Research 45: $117-$ 127.

Montgomery, J.C., and J.A. Macdonald. 1990. Effects of temperature on nervous system: implications for behavioral performance. The American Journal of Physiology 259: R191-R196.

Moyle, P.B., and J.J. Cech. 2003. Fishes: an introduction to ichthyology, 5th ed. Upper Saddle River: Prentice Hall.

Mukhopadhyay, S., and M.K. Poddar. 1990. Higher environmental temperature-induced change in synaptosomal acetylcholinesterase activity of brain regions. Neurochemical Research 15: 231-236.

Noyes, P.D., M.K. McElwee, H.D. Miller, B.W. Clark, L.A. Van Tiem, K.C. Walcott, K.N. Erwin, and E.D. Levin. 2009. The toxicology of climate change: environmental contaminants in a warming world. Environment International 35: 971-986.

Nunes, B., F. Carvalho, and L. Guilhermino. 2004. Acute and chronic effects of clofibrate and clofibric acid on the enzymes acetylcholinesterase, lactate dehydrogenase and catalase of the mosquitofish, Gambusia holbrooki. Chemosphere 57: 15811589 .

Ohkawa, H., N. Ohishi, and K. Yagi. 1979. Assay for lipid peroxides in animal tissues by thiobarbituric acid reaction. Analytical Biochemistry 95: 351-358.

Pickett, G.D., and M.G. Pawson. 1994. Sea bass: biology, exploitation and conservation. Lowestoft, UK: Chapman \& Hall.

Pitcher, T.J., and J.K. Parrish. 1993. Functions of shoaling behaviour in teleosts. In Behaviour of teleost fishes, ed. T.J. Pitcher, 363-439. London, UK: Chapman \& Hall.

Portner, H.O. 2001. Climate change and temperature-dependent biogeography: oxygen limitation of thermal tolerance in animals. Naturwissenschaften 88: 137-146.

Pörtner, H., A.F. Bennett, F. Bozinovic, A. Clarke, M.A. Lardies, M. Lucassen, B. Pelster, F. Schiemer, and J. Stillman. 2006. Trade-offs in thermal adaptation: the need for a molecular to ecological integration. Physiological and Biochemical Zoology 79: 295-313.

Prosser, C.L., and D.O. Nelson. 1981. The role of nervous systems in temperature adaptation of poikilotherms. Annual Review of Physiology 43: 281-300.

Roche, H., and G. Bogé. 1996. Fish blood parameters as a potential tool for identification of stress caused by environmental factors and chemical intoxication. Marine Environmental Research 41: 27-43.

Sanchez, W., and J.M. Porcher. 2009. Fish biomarkers for environmental monitoring within the Water Framework Directive of the European Union. Trac-Trend Analytical Chemistry 28: 150-158.

Schiedek, D., B. Sundelin, J.W. Readman, and R.W. Macdonald. 2007. Interactions between climate change and contaminants. Marine Pollution Bulletin 54: 1845-1856.

Schmidt-Nielsen, K., 1997. Animal physiology: adaptation and environment, 5th ed. Cambridge University Press. 
Szabo, T.M., T. Brookings, T. Preuss, and D.S. Faber. 2008. Effects of temperature acclimation on a central neural circuit and its behavioral output. Journal of Neurophysiology 100: 2997-3008.

Taylor, E.W., G. Egginton, S.E. Taylor, and P.J. Butler. 1997. Factors which may limit swimming performance at different temperatures. In Global warming: implications for freshwater and marine fish, ed. C.M. Wood and D.G. McDonald, 105-134. UK pp: Cambridge University Press, Cambridge.

Thain, J., A.D. Vethaak, and K. Hylland. 2008. Contaminants in marine ecosystems: developing an integrated indicator framework using biological-effect techniques. ICES Journal of Marine Science 65: $1508-1541$

Tierney, K.B. 2011. Behavioural assessments of neurotoxic effects and neurodegeneration in zebrafish. Biochimica et Biophysica Acta (BBA)—Molecular Basis of Disease 1812: 381-389.

Torres, M.A., C.P. Testa, C. Gaspari, M.B. Masutti, C.M. Panitz, R. CuriPedrosa, E.A. de Almeida, P. Di Mascio, and D.W. Filho. 2002. Oxidative stress in the mussel Mytella guyanensis from polluted mangroves on Santa Catarina Island, Brazil. Marine Pollution Bulletin 44: 923-932.

van der Oost, R., J. Beyer, and N.P.E. Vermeulen. 2003. Fish bioaccumulation and biomarkers in environmental risk assessment: a review. Environmental Toxicology and Pharmacology 13: 57-149.

Varò, I., J.C. Navarro, F. Amat, and L. Guilhermino. 2003. Effect of dichlorvos on cholinesterase activity of the European sea bass (Dicentrarchus labrax). Pestic Biochemistry Physics 75: 61-72.
Vassault, A. 1983. Lactate dehydrogenase. In Methods of enzymatic analysis Vol III, enzymes: oxireductases, transferases, ed. H.O. Bergmeyer, 118-126. New York: Academic.

Vinagre, C., T. Ferreira, L. Matos, M.J. Costa, and H.N. Cabral. 2009. Latitudinal gradients in growth and spawning of sea bass, Dicentrarchus labrax, and their relationship with temperature and photoperiod. Estuarine, Coastal and Shelf Science 81: 375-380.

Vinagre, C., D. Madeira, L. Narciso, H.N. Cabral, and M. Diniz. 2012a. Effect of temperature on oxidative stress in fish: lipid peroxidation and catalase activity in the muscle of juvenile seabass, Dicentrarchus labrax. Ecological Indicators 23: 274-279.

Vinagre, C., D. Madeira, L. Narciso, H.N. Cabral, and M.S. Diniz. 2012b. Impact of climate change on coastal versus estuarine nursery areas: cellular and whole-animal indicators in juvenile seabass Dicentrarchus labrax. Mar Ecol-Prog Ser 464: 237-243.

Vinagre, C., L. Narciso, H.N. Cabral, M.J. Costa, and R. Rosa. 2012c. Coastal versus estuarine nursery grounds: effect of differential temperature and heat waves on juvenile seabass, Dicentrarchus labrax. Estuar Coast Shelf S 109: 133-137.

Zar, J.H. 1999. Biostatistical analysis, 4th ed. Upper Saddle River, New Jersey, USA: Prentice Hall, Inc.

Zhang, H.J., L. Xu, V.J. Drake, L. Xie, L.W. Oberley, and K.C. Kregel. 2003. Heat-induced liver injury in old rats is associated with exaggerated oxidative stress and altered transcription factor activation. Faseb Journal 17: 2293-2295. 